\title{
THE COMPRESSION EFFECT ON AERODYNAMIC PROPERTIES OF DIANA SUBMARINE SWIMSUIT
}

\author{
Hazim Moria $^{1,2}$, Firoz Alam ${ }^{1}$, Harun Chowdhury ${ }^{1}$ and Aleksandar Subic ${ }^{1}$ \\ 1 School of Aerospace, Mechanical and Manufacturing Engineering, RMIT University, Melbourne, Australia \\ 2 Department of Mechanical Engineering, Yanbu Industrial College, Yanbu Al-Sinaiyah, Saudi Arabia
}

\begin{abstract}
Aerodynamics is considered as one of the decisive factors in elite sports competitions. By streamlining the athlete's body configuration in fluid, aerodynamic or hydrodynamic resistance can considerably be reduced. In swimming, it is claimed that by utilising the full body swimsuit, the performance can be enhanced. However, there is not enough scientific data to support this. Moreover, it is not clear how a swimsuit can minimise drag. Therefore, the main objective of this work was to study the microscopic effect of swimsuit materials on aerodynamic behaviour under various stretched conditions of a commercially available swimsuit material. The study was conducted experimentally for a range of Reynolds numbers using a cylindrical methodology to quantify the effects of swimsuit materials on aerodynamic properties in wind tunnel environment. The microscopic analysis of swimsuit materials indicated a correlation between the aerodynamic properties and the swimsuit surface structure.
\end{abstract}

\section{Keywords: Speed Sports, Aerodynamic Drag, Wind Tunnel, Macro Scale, Electron Microscope}

\section{INTRODUCTION}

Improvement of aerodynamic performance is critical in a high-speed sport such as swimming. Swimming became one of the major athletic sports and top 10 new sports technologies. The competitive swimming event consists of different distances between $50 \mathrm{~m}$ and $1500 \mathrm{~m}$. These events required excessive energy and speed to achieve best recorded within short wining time margins. Prior studies estimate over $90 \%$ of the swimmer's power output is spent overcoming hydrodynamic resistances [1-2]. These resistive forces were essentially behind the generation of drag during swimming. Reducing the hydrodynamic resistance can significantly improve overall swimming performance [3]. The hydrodynamic resistance can generally be divided into two categories: (i) passive resistance and (ii) active resistance. The passive resistance is generally measured by towing the swimmer without any physical movements $[1,4-5]$. The passive drag is directly influenced by the body shape and outfits. The active resistance is measured for the swimmer during swimming with the physical movement. The active drag can be found once the propulsive force is computed. Vorontsov et al. [1] and Toussaint et al. [6-7] have suggested that the overall drag affecting a swimmer and could be categorized as: (i) form drag, (ii) wave drag, and (iii) skin friction drag. Form drag is the resistance to motion due to the shape of the body, the wave drag is associated with the work required to generate waves and skin friction is the resistance to 
motion due to the surface area of the body. The form and skin friction drag depend on the Reynolds number $(\mathrm{Re})$ :

$\operatorname{Re}=\frac{\rho V l}{\mu}$

The wave drag depends on the Froude number $(\mathrm{Fr})$ :

$F r=\frac{V}{\sqrt{g l}}$

In competitive swimming, where hundredths of a second can separate the winner from the loser, the aerodynamic drag minimization can play a positive role. At present, most competitive swimmers attempt to take advantage of various means including swimsuits to enhance their performance. The modern swimsuits have evolved through a series of style changes and designs over the decades to its current form [8-9]. The aero/hydrodynamic behaviour of modern swimsuits is not well studied and reported to the public domain. What sort of advantages especially the aero/hydrodynamic aspects are gained by using these well publicized swimsuits are not known. It is believed that the surface morphology of commercial swimsuit could play a vital role in aero/hydrodynamic advantages [10].

Therefore, the primary objectives of this study are to experimentally study of aerodynamic behaviour of a commercial swimsuit "Diana" under a range of wind speeds and surface morphology under tension and without tension. Moreover, it is well known that the technological innovation in both design and materials has allowed achieving its current standing in both absolute performance and its aesthetics (e.g., Strangwood and Subic [11], Chowdhury et al. [12-13] and Moria et al. [10-14]).

\section{EXPERIMENTAL PROCEDURE AND METHOD}

\subsection{Macro SCALE TeSting}

The human body is not a streamlined shape and caused a lot of flow separations around it. The drag generated by the body (pressure, wave and friction drag) is significantly larger than the drag generated by swimmers outfits (textile). Therefore, the drag generated by the swimsuit must be evaluated in isolation by using a macro scale testing. In order to measure the aerodynamic properties of the swimsuit material, a macro scale testing methodology using a standard cylinder has been developed in RMIT University. The schematic view of this standardized macro scale testing methodology using a cylinder is shown in Figure 1.

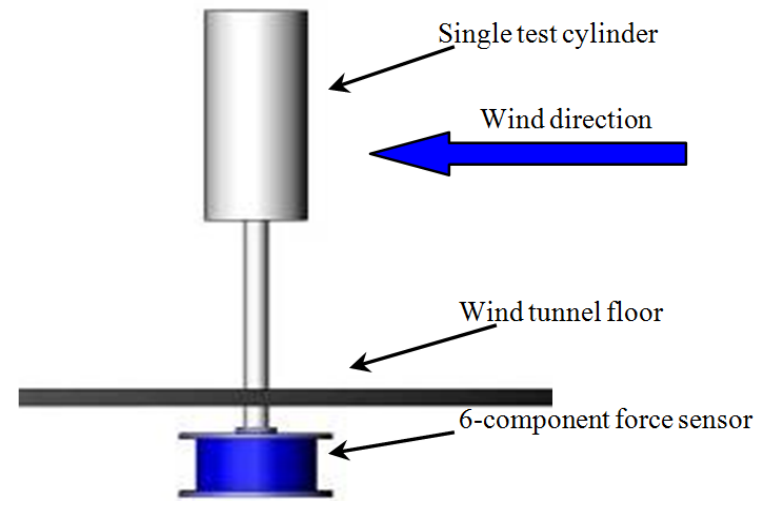

Fig 1. Schematic of cylinder methodology [8]

With a view to obtain aero/hydrodynamic properties experimentally for a commercially available swimsuit, a $90 \mathrm{~mm}$ diameter and $220 \mathrm{~mm}$ length cylinder was manufactured. The cylinder was made of PVC material and used some filler to make it structurally rigid. The cylinder was vertically supported on a six component sensor (type JR3) that had a sensitivity of $0.05 \%$ over a range of 0 to 200 $\mathrm{N}$. For more details of this method can be found in Chowdhury et al. [12-13]. 
The aerodynamic forces and their moments were measured for a range of Reynolds numbers $(\mathrm{Re})$ based on cylinder diameter and varied wind tunnel air speeds (from $30 \mathrm{~km} / \mathrm{h}$ to $140 \mathrm{~km} / \mathrm{h}$ with an increment of $10 \mathrm{~km} / \mathrm{h}$ ). Each test was conducted as a function of swimsuit's fabric tensions.

\subsection{Fabric Tension Measurement}

An Instron Machine 4466 was used to evaluate the fabric strength. Two adapters (grips made of Aluminum) were designed to hold the two ends of fabric uniformly. One attachment was used for the upper end of the textile connected to the moving part of Instron loading arm while the other attachment was used to hold the base. The maximum capacity of the used Instron machine was $10,000 \mathrm{~N}$ of tensile force. The rubber slabs were used on the interior side of the Aluminum adapter pales to make sure that the fabric would not slab out of the grip. The dimensions of the plate are $250 \mathrm{~mm} \times 60 \mathrm{~mm}$ $\times 10 \mathrm{~mm}$ which is bigger than the sample. Three samples of Diana swimsuit material were prepared for each test variable to minimise the error margin. The dimensions of the sample are $220 \mathrm{~mm} \times 280 \mathrm{~mm} \times 0.27$ $\mathrm{mm}$. The experimental setup using Instron along with the sample under various tensions are shown in Figure 2.

Figure 3 shows the results for tension measurements of the fabric sample used in this study. According to the standard test method for the breaking strength and elongation of textile fabrics (ASTM-D5034), the loading rate was set at $100 \mathrm{~mm} / \mathrm{min}$. Also, the fabric sample was stretched till it reached $100 \mathrm{~mm}$ extension from zero.

\subsection{EXPERIMENTAL FACILITIES}

The RMIT Industrial Wind Tunnel was used to measure the aerodynamic properties of swimsuit fabrics. The tunnel is a closed return circuit wind tunnel with a turntable to simulate the cross wind effects. The maximum speed of the tunnel is approximately $150 \mathrm{~km} / \mathrm{h}$.

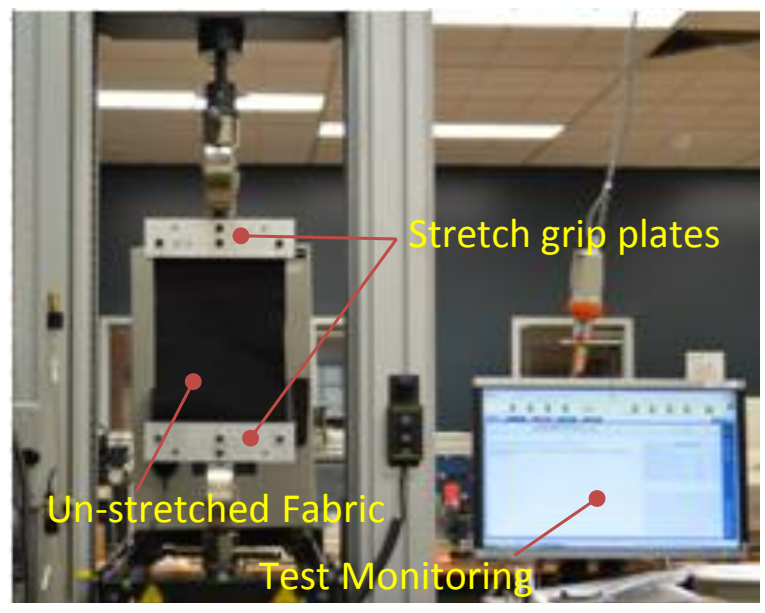

(a) Un-stretched fabric test

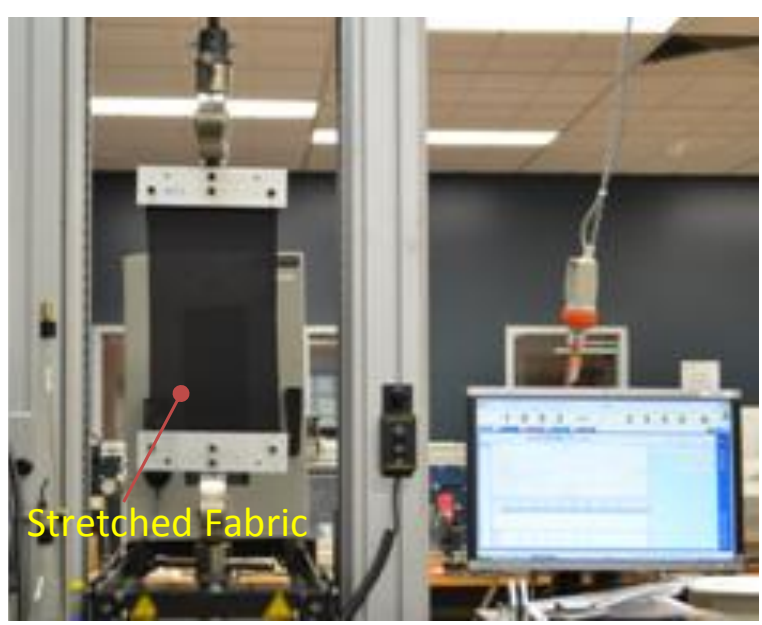

(b) Stretched fabric test

Fig 2. Setup of fabric tension measurement

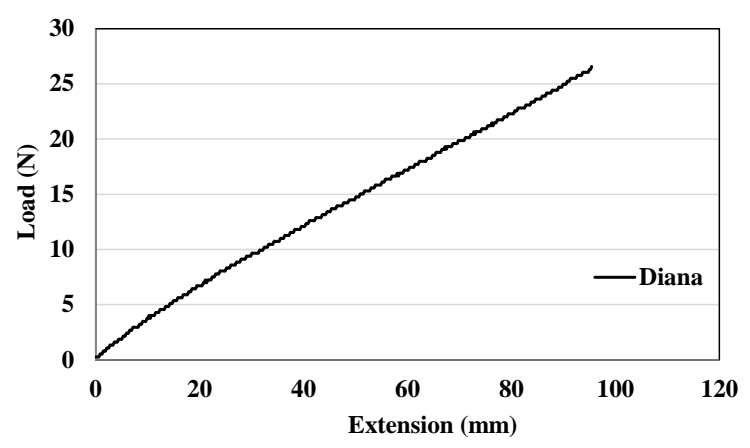

Fig 3. Fabric extension versus tensile load

The rectangular test section dimensions are 3 meters wide, 2 meters high and 9 meters long, and the tunnel's cross sectional area is 6 
square meters. A plan view of the tunnel is shown in Figure 4. The tunnel was calibrated before and after conducting the experiments and air speeds inside the wind tunnel were measured with a modified National Physical Laboratory (NPL) ellipsoidal head Pitot-static tube (located at the entry of the test section) which was connected through flexible tubing to a Baratron pressure sensor made by MKS Instruments, USA. The cylinder was connected through a mounting sting with the JR3 multi-axis load cell, also commonly known as a 6 degree of freedom force torque sensor made by JR3, Inc., Woodland, USA. The sensor was used to measure all three forces (drag, lift and side forces) and three moments (yaw, pitch and roll moments) at a time. Each set of data was recorded four times for 20 seconds time average with a frequency of $20 \mathrm{~Hz}$ ensuring electrical interference is minimised. Multiple data sets were collected at each speed tested and the results were averaged for minimising the further possible errors in the experimental raw data. More details about the wind tunnel can be found in Alam et al. [15].

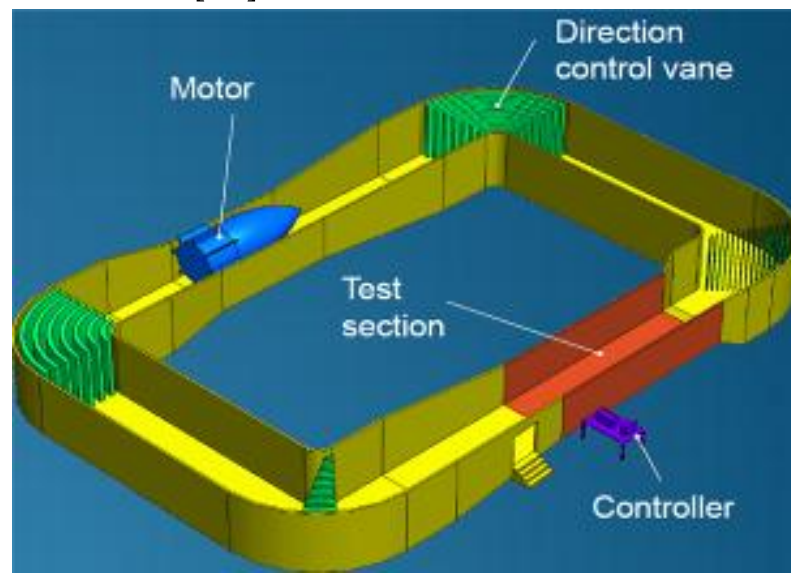

Fig 4. Isometric view of RMIT Industrial Wind Tunnel

The bare cylinder was tested initially in order to benchmark the aerodynamic properties with the published data. Then, the cylinder was wrapped with varied tensioned swimsuit fabrics to measure their aerodynamic drag. The fabrics were joined together by creating a seam which was placed at the rear of the cylinder (e.g., $180^{\circ}$ orientation) to minimise the effect of seam on aerodynamic properties [8-9]. Based on the stretch measured by Instron, the sample length was determined. The drag of the cylinder support was measured and subtracted from the drag of the cylinder and support. Figure 5 shows the cylinder fitted with test fabric for the wind tunnel testing. More details about the end effects of the bare cylinder (3D effects) can be found in Chowdhury et al. [12].

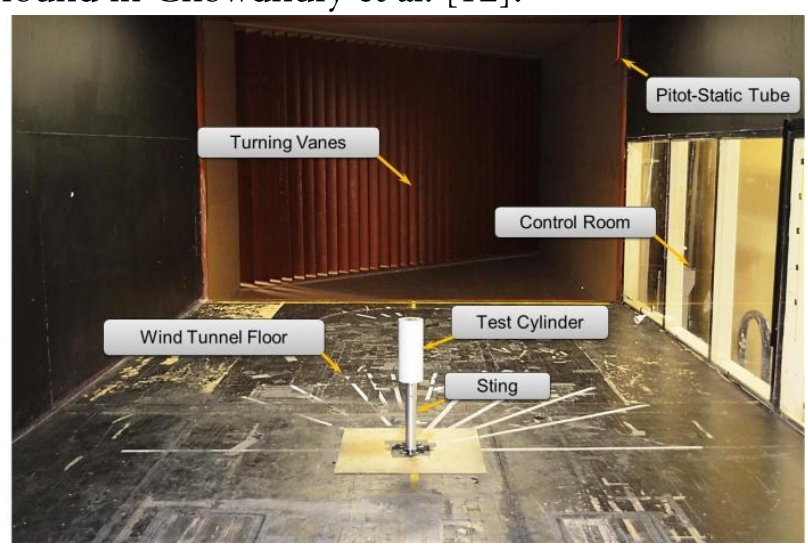

Fig 5. Experimental bare cylinder setup in RMIT Industrial Wind Tunnel

\subsection{DESCRIPTION OF SWIMSUIT FABRIC}

A brand new of Diana Submarine swimsuit material was selected for this study. It is composed of woven 66\% Nylon and 34\% Lycra. Figure 6 shows the Diana fabric fitted onto the cylinder under different tension.

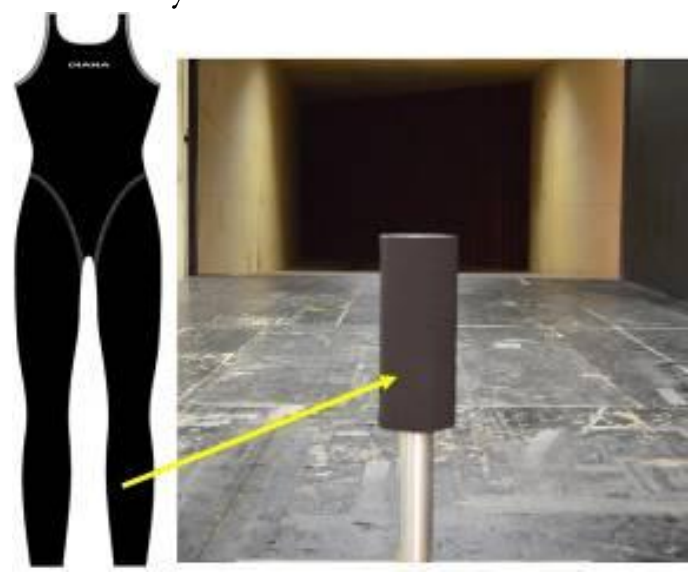

Fig 6. Diana submarine swimsuit used in this study 


\section{RESULTS AND DISCUSSION}

\subsection{MicrostruCture ANALYSIS}

Stretching the fabric or over fitting on the body may change the surface structure of the fabric. The aerodynamic properties can be affected by changing the structure of the fabric. The importance of microscopic study is to correlate the aerodynamic properties with microstructure of the fabric. The optical images without magnification were taken under various tensions to illustrate the real fabric surface as shown in Figure 7. However, it was difficult to understand any substantial surface morphological changes without magnification. Therefore, images with $15 \mathrm{X}$ magnification were taken in order to determine the number of weft and warp threads from the fabric surface (see Figure 8). Table 1 shows the number of weft and warp threads per $\mathrm{cm}$. The number of weft threads decreases with increase in tension on the fabric weft direction. In order to understand the fabric microstructure of Diana swimsuit fabric for more detailed analysis, an Electron Scanning Microscope (ESM) was used to obtain the fabric features at 100X, 800X and 1000X magnification for the stretched and un-stretched conditions. Figure $9 \mathrm{a}$ and $\mathrm{b}$ shows the fibre orientation and dimensions for both un-stretched and stretched fabric. It can be seen in Figure 9 a, the un-stretched fabric was different in shape compared to the stretched fabric as shown in Figure $9 \mathrm{~b}$. The total area of the weft and warp was 5.930 $\mathrm{mm}^{2}$. Also, the number of weft and warp threads for un-stretched fabric was 14 and 11 respectively, while the weft and warp threads for stretched fabric was accounted for 13 and 10. Figure $10 \mathrm{a}$ and $\mathrm{b}$ shows the areas of weft and warp threads for the un-stretched and stretched fabric which are $0.0387 \mathrm{~mm}^{2}$ and $0.0458 \mathrm{~mm}^{2}$, however, the empty space (gap) is $0.0127 \mathrm{~mm}^{2}$ and $0.000157 \mathrm{~mm}^{2}$ respectively. It was also calculated that, the weft and warp threads to have width of 0.085 $\mathrm{mm}^{2}$ and a thread diameter of $0.0209 \mathrm{~mm}$. The applied tension on the fabric may contribute to the influences of permeability, buoyancy and porosity of fabric.

TABLE 1. THREAD COUNT OF THE FABRIC UNDER TENSION

\begin{tabular}{ccc}
\hline $\begin{array}{c}\text { Fabric extension } \\
(\mathrm{mm})\end{array}$ & \multicolumn{2}{c}{ Thread count per cm } \\
\cline { 2 - 3 } 0 & weft & warp \\
\hline 10 & 50 & 60 \\
20 & 54 & 60 \\
30 & 52 & 60 \\
40 & 49 & 60 \\
50 & 48 & 60 \\
60 & 46 & 60 \\
70 & 45 & 60 \\
80 & 44 & 60 \\
90 & 43 & 60 \\
100 & 42 & 60 \\
\hline
\end{tabular}

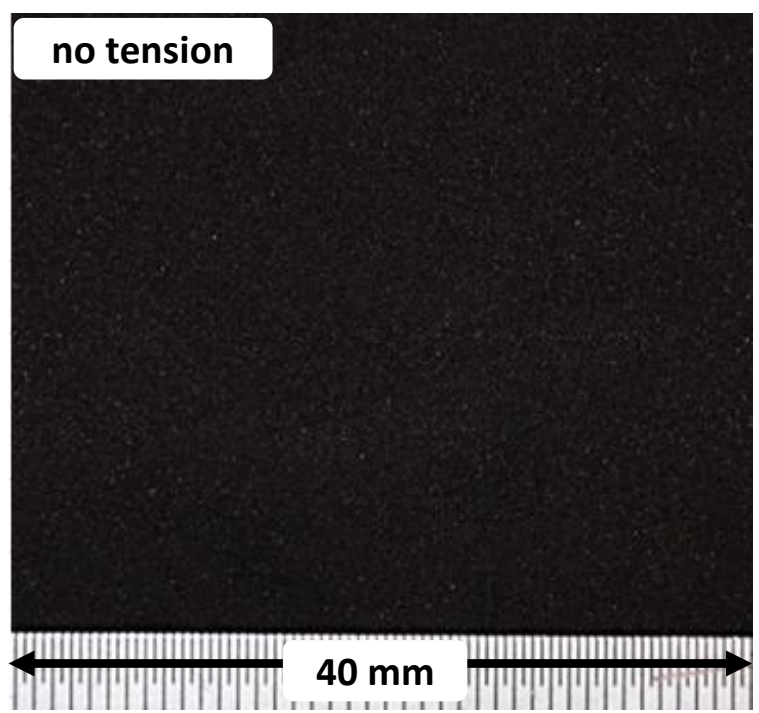

(a) $0 \mathrm{~mm}$ extension 


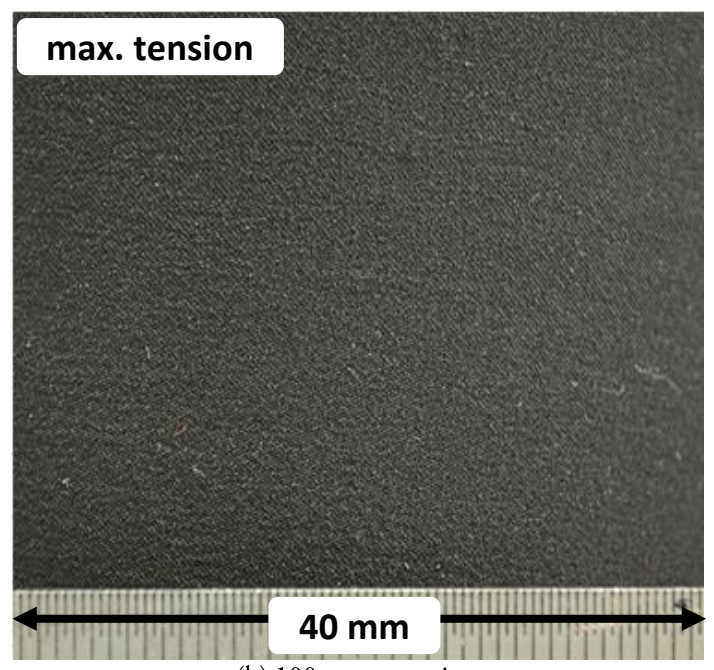

(b) $100 \mathrm{~mm}$ extension

Fig 7. Optical images of un-stretched and stretched fabrics (without magnification)

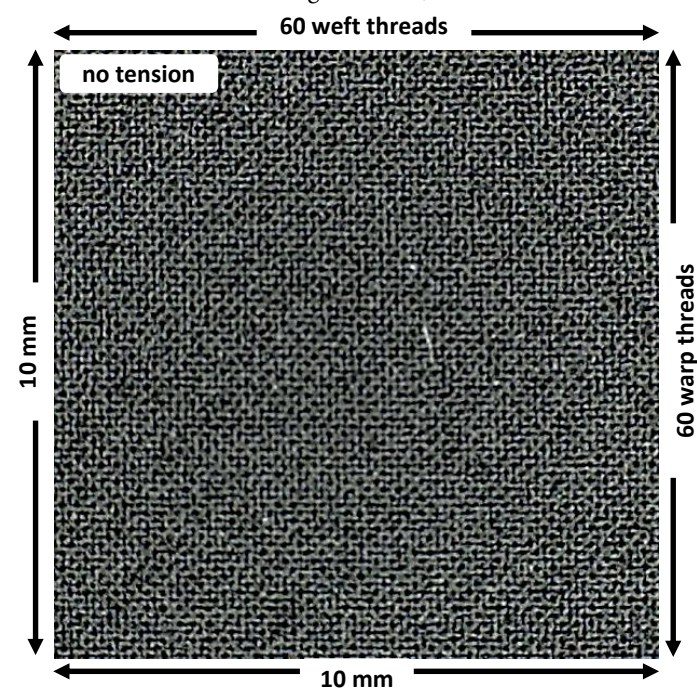

(a) $0 \mathrm{~mm}$ extension

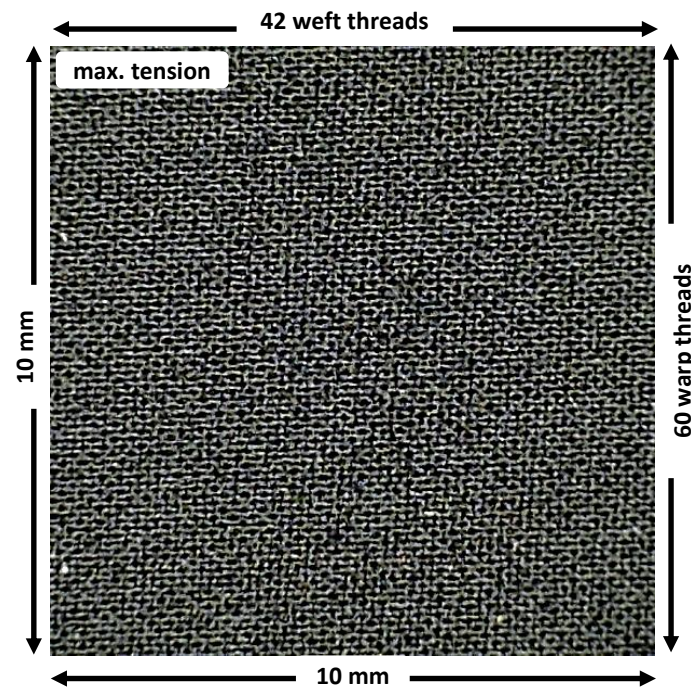

(b) $100 \mathrm{~mm}$ extension

Fig 8. Optical images for un-stretched and stretched fabrics (15X magnification)

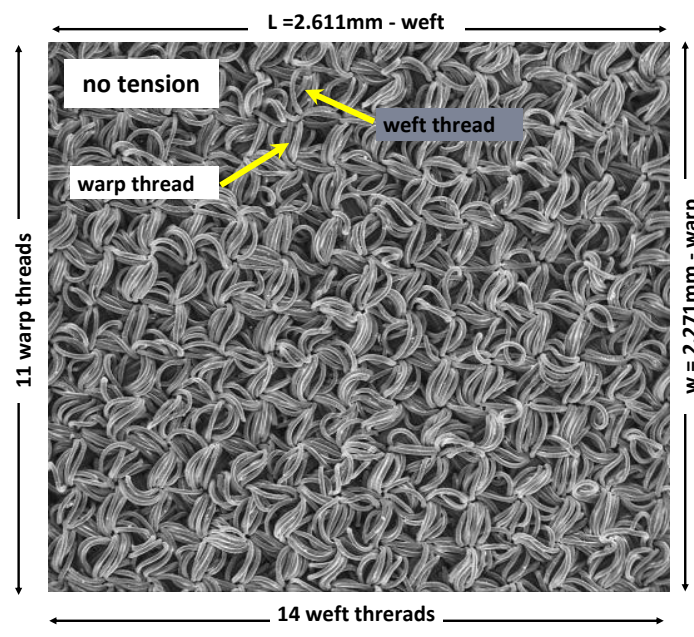

(a) Un-stretched fabric

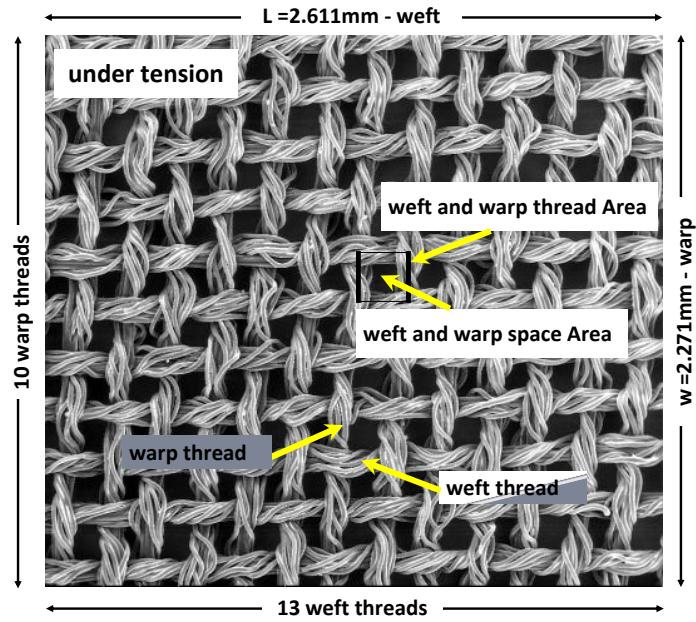

(b) Stretched fabric

Fig 9. Surface profile using an Electron microscope (100X magnification)

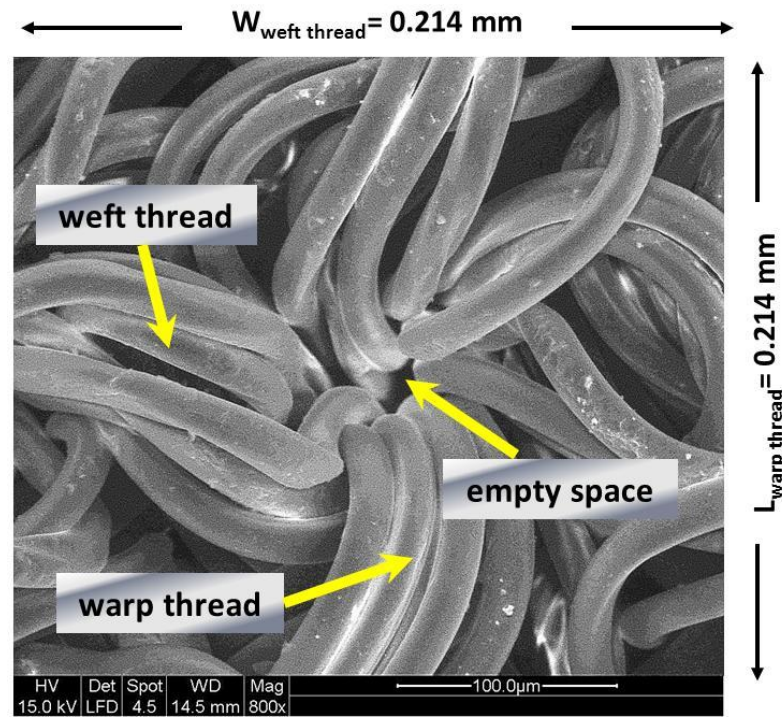

(a) Un-stretched weft and warp thread 


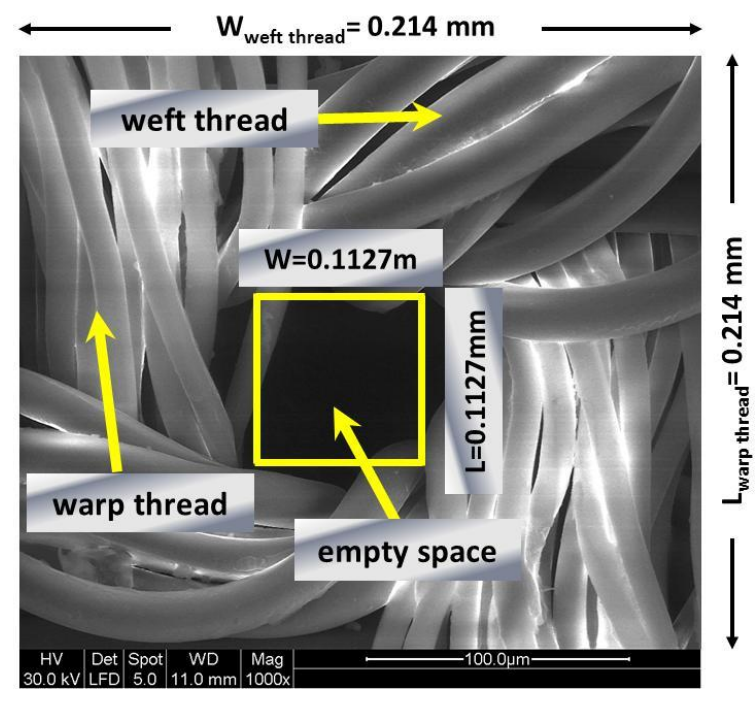

(b) Stretched weft and warp thread

Fig 10. Weft and warp thread surface profile using an Electron microscope (800X and 1000X magnification)

\subsection{AERODYNAMIC RESULTS}

As mentioned earlier, the purpose of this study was to measure the aerodynamic properties (lift and drag) under different tension on fabrics. Hence, in this paper, only drag force (D) data, and its dimensionless quantity drag coefficient $\left(\mathrm{C}_{\mathrm{D}}\right)$, are presented. The $C_{D}$ was calculated by using the following formula:

$$
C_{D}=\frac{D}{1 / 2 \rho V^{2} A}
$$

The drag force (D) as a function of wind speed $(\mathrm{V})$, and the drag coefficient $\left(\mathrm{C}_{\mathrm{D}}\right)$ as a function of Reynolds numbers (Re) for a range of tensioned fabrics are presented in Figures 11 and 12. In order to compare the results of swimsuit fabric in stretched and unstretched conditions, the drag force (D) and $\mathrm{C}_{\mathrm{D}}$ for the bare cylinder were also shown in these figures. Figures 11 shows the drag for bare cylinder (without fabric) is continuously increasing without any abrupt changes as expected [16-21]. Similarity, the drag force of the fabric with no tension is continuously increasing as the bare cylinder. However, the magnitude of drag force is lower compared to the bare cylinder. In contrast, the drag forces for the fabrics under various tensions underwent flow transition at different speeds.

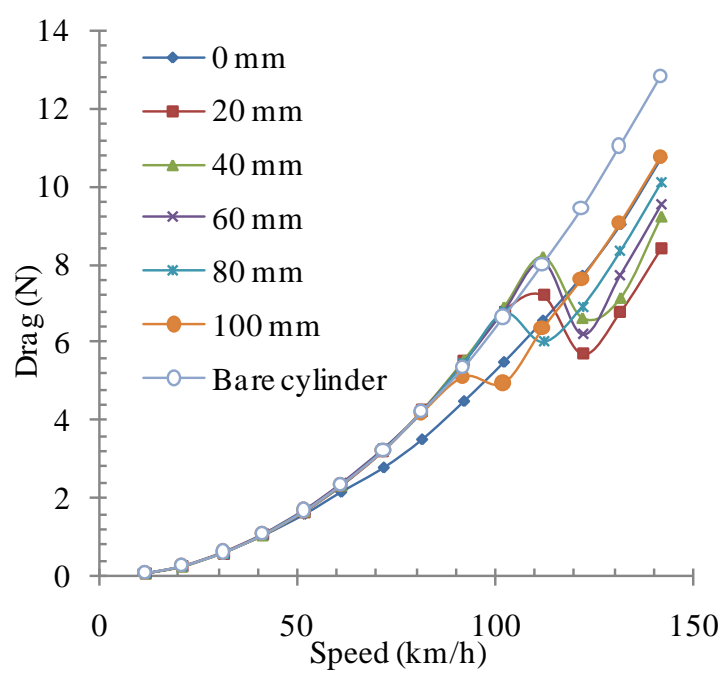

Fig 11. Drag variation with speeds

The $C_{D}$ variations with $R e$ as shown in Figure 12 clearly indicated that the swimsuit fabrics have underwent the flow transition from laminar to turbulent flow regimes at different speeds. The $0 \mathrm{~mm}$ extension (normal fit), has undergone early transition at $30 \mathrm{~km} / \mathrm{h}$ (e.g., $\left.\operatorname{Re}=5.08 \times 10^{4}\right)$ compare to other cases. On the other hand, the $100 \mathrm{~mm}$ extension (maximum tension) tested in this study delays the transition from laminar to turbulent flow regimes compared other fabrics under tension. However, the $0 \mathrm{~mm}$ and $100 \mathrm{~mm}$ extension have the same $C_{D}$ at high speed. The fabric tension with $40 \mathrm{~mm}$ and $60 \mathrm{~mm}$ extension delays the flow transition significantly later (transition starts at $110 \mathrm{~km} / \mathrm{h}$ and ends at 130 $\mathrm{km} / \mathrm{h}$ for $40 \mathrm{~mm}$ extension and start at 110 $\mathrm{km} / \mathrm{h}$ and end at $120 \mathrm{~km} / \mathrm{h}$ for $60 \mathrm{~mm}$ extension). However, once the transition occurs, the $C_{D}$ values become significantly lower. Among all fabric samples under tension, the $20 \mathrm{~mm}$ extension has the lowest $C_{D}$ value (transition occurs at $100 \mathrm{~km} / \mathrm{h}$ ) compared to other two samples with 40 and $60 \mathrm{~mm}$ extension. 


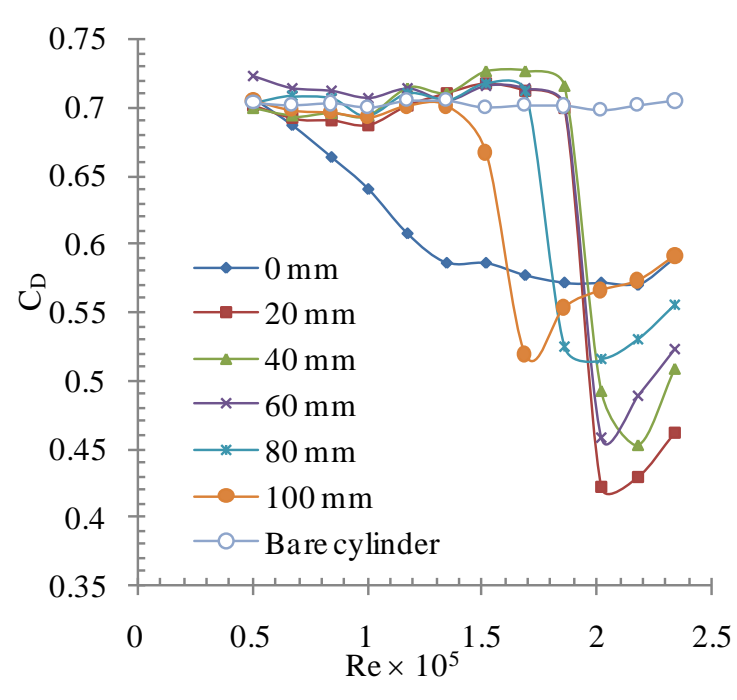

Fig 12. $C_{D}$ variation with $\mathrm{Re}$

\section{CONCLUSION}

The following conclusions were made based on the experimental study presented here:

- The surface structure with varied stretched and un-stretched fabrics has a notable effect on the aero/hydrodynamic drag.

- Diana fabric under lower extension $(20 \mathrm{~mm})$ has relatively better advantage due to lower $\mathrm{C}_{\mathrm{D}}$ value.

- The fabrics under moderate and higher tensions (40,60 and $80 \mathrm{~mm}$ extensions) also have aerodynamic advantages at higher Reynolds numbers.

- The flow transition can be controlled by fabric surface profiles in order to minimize the aerodynamic drag.

- The normal fit fabric (no extension) had an early flow transition thereby can be beneficial at lower Reynolds number at the same time it has highest $C_{D}$ at the higher Reynolds number.
- Right selection of swimsuit fabric and size for the athletes is utmost important for achieving aero/hydrodynamic advantages.

\section{ACKNOWLEDGEMENTS}

We express our sincere gratitude and thanks to the Government of Kingdom of Saudi Arabia for providing the PhD Scholarships to the first author, also grateful to Mr. Peter Tkatchyk and Mr. Ashwin Date, School of Aerospace, Mechanical and Manufacturing Engineering, RMIT University for their assistance with the fabric tensile testing and technical drawing. We acknowledge the assistance received from Mr. Phil Francis and Mr. Peter Rummel, School of Applied Sciences, RMIT University with the Electron Scanning Microscope Analysis.

\section{NOMENCLATURE}

$\begin{array}{lll}\text { Symbol } & \text { Meaning } & \text { Unit } \\ R e & \text { Reynolds Number } & \\ C_{D} & \text { Drag Coefficient } & \\ D & \text { Drag Force } & \\ \rho & \text { Fluid Density } & (\mathrm{N}) \\ V & \text { Wind Speed } & \left(\mathrm{kg} / \mathrm{m}^{3}\right) \\ A & \text { Projected Frontal Area of } & (\mathrm{m} / \mathrm{s}) \\ d & \text { Cylinder } & \left(\mathrm{m}^{2}\right) \\ \mu & \text { Diameter of Cylinder } & (\mathrm{m}) \\ l & \text { Dynamic Viscosity } & \left(\mathrm{N} . \mathrm{s} / \mathrm{m}^{2}\right) \\ g & \text { Characteristic Length } & (\mathrm{m}) \\ & \text { Gravitational Acceleration } & \left(\mathrm{m} / \mathrm{s}^{2}\right)\end{array}$

\section{REFERENCES}

[1] Vorontsov, A. R. and Rumyantsev, V. A., "Resistive forces in swimming \& propulsive forces in swimming”, Biomechanics in Sport (edited by Zatsiorsky) Blackwell, UK, 2000.

[2] Nakashima, M. and Sato, Y., "Optimization of arm stroke in freestyle swimming by Simulation", Engineering of Sports III, Vol. 1, pp 207-211, 2009 . 
[3] Rushall, B. S., Sprigings, E. J., Holt, L. E., and Cappaert, J. M., "A re-evaluation of forces in swimming”. Journal of Swimming Research, Vol. 10, pp 6-30, 1994.

[4] Jiskoot, J., and Clarys, J.P., "Body resistance on and under the water surface". In L. Lewillie \& J.P. Clarys (Eds.), Swimming II, Baltimore: University Park Press, pp. 105-109, 1975.

[5] Lyttle, A.D., Blanksby, B.A., Elliott, B.C., and Lloyd, D.G., "Optimal depth for streamlined gliding”. In K.L. Keskinen, P.V. Komi, \& A.P. Hollander (Eds.), Biomechanics and Medicine in Swimming VIII, Jyvaskyla: Gummerus Printing, pp. 165-170, 1999.

[6] Toussaint H.M., Truijens M., Elzinga M.J., Ven A.v.d., Best H.d., Snabel B. and Groot G.d., "Effect of a fast-skin body suit on drag during front crawl swimming". Sport Biomechanics, Vol. 1, pp. 1-10, 2002.

[7] Toussaint H.M., Bruinink L., Coster R., Looze M.d., Rossem B.v., Veenen R.v. and Groot G.d., "Effect of a triathlon wet suit on drag during swimming", Medicine and Science in Sports and Exercises, Vol. 21, pp. 325-328, 1989.

[8] Moria, H., Chowdhury, H., Alam, F., Subic, A., Smits, A. J., Jassim, R., and Bajaba, N. S., "Contribution of swimsuits to swimmer's performance", Procedia Engineering, Elsevier, UK, Vol 2, no.2, pp 2505-2510, , 2010.

[9] Moria, H., Chowdhury, H., Alam, F. and Subic, A.,"Aero/hydrodynamic study of Speedo LZR, TYR Sayarona and Blueseventy Pointzero03 swimsuits", In Jordan Journal of Mechanical and Industrial Engineering, Hashemite University in corporation with the Jordan Scientific Research, Amman, Jordan, Vol. 5, no. 1, pp. 83-88, ISSN: 1995-6665, 2011.

[10] Moria, H., Chowdhury, H. and Alam, F., "Microstructures and aerodynamics of commercial swimsuits" Procedia Engineering, Elsevier, UK, Vol 13, no.2, pp 389-394, 2011.

[11] Strangwood, M. and Subic, A., "Modelling of materials for sports equipment", Materials in Sports Equipment, Woodhead Publishing Ltd., Cambridge, UK, Vol. 2, 2007.

[12] Chowdhury, H., Alam, F., Mainwaring, D., Subic, A., Tate, M., Forster, D. and BeneytoFerre, J., "Design and methodology for evaluating aerodynamic characteristics of sports textiles",
Sports Technology, Vol. 2, no. 3-4, pp 81-86, 2009.

[13] Chowdhury, H., Alam, F. and Subic, A., "Aerodynamic performance evaluation of sports textile", Procedia Engineering, Elsevier, UK, Vol. 2, no.2, pp 2517-2522, , 2010.

[14] Moria, H., Chowdhury, H., Alam, F., Subic, A. and Smits, A. J., "Hydrodynamics of swimsuits", Proceedings of the 13th Asian Congress of Fluid Mechanics(ACFM2010,17-21 December, Dhaka, Bangladesh), Vol. 2, pp 938-941, ISBN: 978984-33-2214-2, 2010.

[15] Alam, F., Zimmer, G., Watkins, S., "Mean and time-varying flow measurements on the surface of a family of idealized road vehicles", Experimental Thermal and Fluid Sciences, Vol. 27, no. 5, pp 639-654, 2003.

[16] White, F. M., "Fluid Mechanics (5th ed)", McGrow-Hill, 2003.

[17] Fage, A. and Warsap, G.H., "The effect of turbulence and surface roughness on the drag of a circular cylinder", British Aerospace Resourse Council, memo 1283, 1929.

[18] Zdravkovich, M.M.,"Flow around circular cylinder, Applications, Oxford University Press, ISBN:0198565615, 1997.

[19] Fu, H., "Preliminary analysis of skating motion", Applied mathematics and mechanics, Vol.23, no.1, pp.114-118, 2002.

[20] Achenbach, E., "The effect of surface roughness on the heat transfer from a circular cylinder to the cross flow of air", International Journal of Heat and Mass Transfer, Vol.20, pp. 359-369, 1977.

[21] Oggiano, L., Leirdal, S., Saetran, L. and Ettema, G., "Aerodynamic optimization and energy saving of cycling postures for international elite level cyclists", The engineering of sport, Vol. 1, no. 7, pp. 597-604, 2008. 


\section{تأثير نوعية ملابس السباحة على المقاومة الهيدروديناميكية أثناء السباحة}

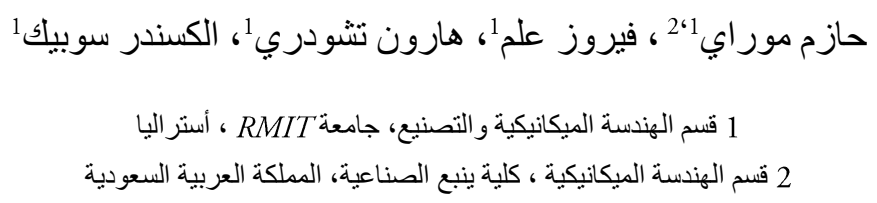

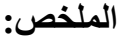

تعتبر الديناميكا الهو ائية واحدة من العو امل الحاسمة في نخبة المنافسات الرياضية. يمكن إلى حد كبير تخفيض المقاومة الهو ائية أو الهيدروديناميكية بواسطة انسيابية جسم الرياضي. في السباحة، يزعم أنه يمكن تحسين الأداء من خلال الاستفادة من ملابس السباحة كامل الجسم. ومع ذلك، ليس هناك بيانات علمية كافية لدعم هذا. و علاوة على ذلك، ليس من الو اضح كيف يمكن لملابس السباحة أن تقلل من المقاومه. ولذا، فإن الهدف الرئيسي من هذا العمل هو در اسة مجهرية لمو اد ملابس السباحة وتأثير ها على السلوك الهوائية تحت ظل ظروف مختلفة من الثد على ملابس السباحة المتاحة تجاريا. أجريت الدراسة التجريبية لمجموعة من أرقام رينولدز باستخدام منهجية أسطو اني لتقدير آثار المواد ملابس السباحة على خصائص البيئة الهوائية في نفق الرياح. وأثنار التحليل المجهري للمو اد ملابس السباحة وجود علاقة بين الخصائص الديناميكية الهوائية وهيكل سطح ملابس السباحة. 